\title{
Communication \\ Multiple Roles of Prostaglandin E2 Receptors in Female Reproduction ${ }^{\dagger}$
}

\author{
Yao Ye ${ }^{1, \ddagger}$, Peng Lin ${ }^{2, \ddagger}$, Junyan Zhu ${ }^{3}$, Udo Jeschke ${ }^{2,4, *(1)}$ and Viktoria von Schönfeldt ${ }^{2}$ \\ 1 Department of Gynecology and Obstetrics, Shanghai Jiao Tong University School of Medicine, \\ Kongjiang Rd. 1665, Shanghai 200092, China; yeyaoeryida@163.com \\ 2 Department of Obstetrics and Gynecology, University Hospital, LMU Munich, 81377 Munich, Germany; \\ Lin.Peng@med.uni-muenchen.de (P.L.); Viktoria.Schoenfeldt@med.uni-muenchen.de (V.v.S.) \\ 3 Department of Gynecology and Obstetrics, School of Medicine, Shanghai Jiao Tong University, \\ Dongfang Rd. 1630, Shanghai 200127, China; zhuzhu198109@163.com \\ 4 Department of Gynecology and Obstetrics, University Hospital Augsburg, Stenglinstr. 2, \\ 86156 Augsburg, Germany \\ * Correspondence: udo.jeschke@med.uni-muenchen.de; Tel.: +49-89-4400-54240 \\ $+\quad$ This paper is an extended version of Junyan Zhu's PhD thesis, 2019. \\ $\ddagger$ These two authors contributed equally to this work.
}

Received: 12 March 2020; Accepted: 4 May 2020; Published: 6 May 2020

check for updates

\begin{abstract}
Among prostaglandins, Prostaglandin E2 (PGE2) (PGE2) is considered especially important for decidualization, ovulation, implantation and pregnancy. Four major PGE2 receptor subtypes, EP1, EP2, EP3, EP4, as well as peroxisome proliferator-activated receptors (PPARs), mediate various PGE2 effects via their coupling to distinct signaling pathways. This review summarizes up-to-date literatures on the role of prostaglandin E2 receptors in female reproduction, which could provide a broad perspective to guide further research in this field. PGE2 plays an indispensable role in decidualization, ovulation, implantation and pregnancy. However, the precise mechanism of Prostaglandin E2 (EP) receptors in the female reproductive system is still limited. More investigations should be performed on the mechanism of EP receptors in the pathological states, and the possibility of EP agonists or antagonists clinically used in improving reproductive disorders.
\end{abstract}

Keywords: prostaglandin E2 receptors (EPs); peroxisome proliferator-activated receptors (PPARs); endometrium; ovary; trophoblast

\section{Introduction}

Prostaglandin (PG) E2, one of the prostanoid family, is a lipid mediator formed commonly in human bodies, and it plays the central role in female fertilization [1]. PGE2 is the major prostaglandin synthesized by the endometrium [2], ovary [3] and placenta [4]. PGE2 plays an indispensable role in decidualization, ovulation, implantation and pregnancy. It can modulate the balance ratio of Th1/Th2 (T helper cell type 1/T helper cell type 2) [5], regulate chemokine secretions [5] and inhibit lymphocyte alloreactivity [6].

The biosynthesis of PGE2 is a three-step process and three types of enzymes are included (Figure 1). Firstly, arachidonic acid (AA) is released from acid plasma membrane phospholipids, after hydrolysis of the sn-2 bond by phospholipase A2 (PLA2) [7]. The released AA is then converted to prostaglandin G2 (PGG2) and prostaglandin H2 (PGH2), the two unstable intermediates, by the action of cyclooxygenase (COX) [8]. Three isoforms of COX enzymes have been described: COX-1, COX-2, and COX-3. Finally, the unstable precursor, PGH2, is catalyzed into different prostanoids, including PGE2, PGF2 $\alpha$, PGD2, PGI2 and thromboxane A2 (TXA2), by their respective terminal 
PG synthase enzymes: PGE synthase (PGES), Prostacyclin (PGI) synthase, prostaglandin D (PGD) synthase, prostaglandin F (PGF) synthase and thromboxane synthase [9]. Following synthesis, PGE2 is transported across the plasma membrane by multidrug resistance protein 4 (MRP4) [10] and activates its receptors. Alternatively, newly synthesized extracellular PGE2 is imported back into cells via the prostaglandin transporter (PGT), to suppress the signal pathway by preventing PGE2 from attaching to prostaglandin $\mathrm{E} 2$ receptors (EPs) [11,12].

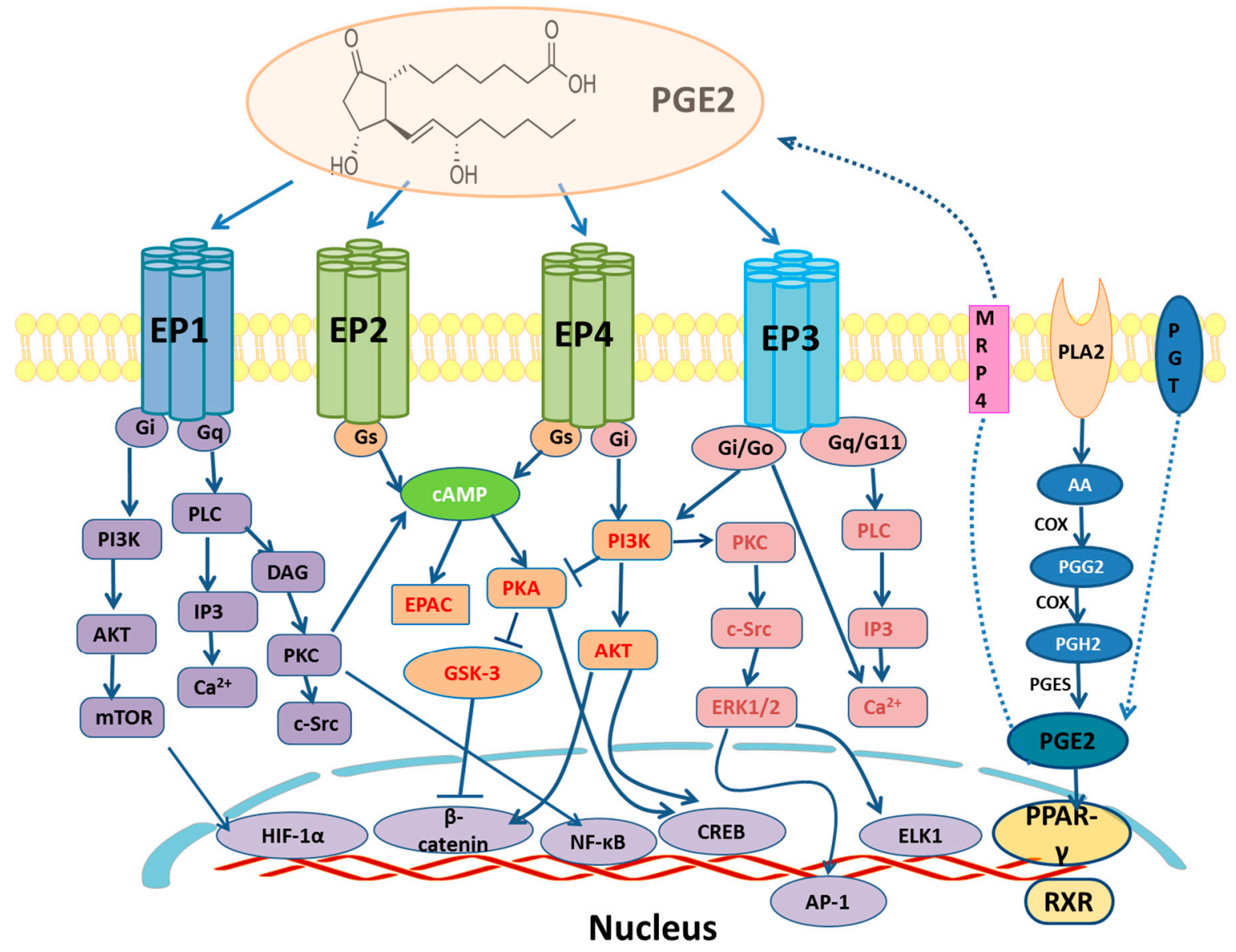

Figure 1. PGE2 biosynthesis and signaling pathways. PGE2 exerts its effect via binding four G protein-coupled receptor subtypes (EP1-4). PGE2 coupling with EP1 activates Gi and PI3K-AKT-mTOR signaling to enhance the transcription of HIF- $\alpha$. EP1 also induces Gq and activates the PLC/DAG/PKC pathway to stimulate NF- $\kappa$ B gene expression. PGE2 binding to EP2 and EP4 induces Gs, increases intracellular cAMP levels, and activates the PKA pathway to stimulate the transcription of beta-hCG via CREB. EP4 combines to $\mathrm{Gi}$ and activates the PI3K/AKT pathway to stimulate NF- $\mathrm{KB}$ and CREB transcription expression. The activated EP3/Gi1 can stimulate ERK1/2, which eventually enhances PAI-1 and ERK-1 gene transcription. EP3 also couples with Gq and activates the PLC/IP3/Ca ${ }^{2+}$ pathway. Additionally, AA is released, and ultimately catalyzed into PGE2 and increased CREB and RXR transcription to enhance various downstream gene expression. COX—cyclooxygenase; CREB-response element binding protein; $\mathrm{cAMP}$ — cyclic adenosine monophosphate; $\mathrm{Gi}-\mathrm{G}$ protein alpha inhibitor; Gq-G-protein alpha $\mathrm{q}$; Gs-G protein alpha stimulator; PAI-1-plasminogen activator inhibitor type 1; ERK1/2 - extracellular signal-regulated kinases 1/2; PGE2-prostaglandin E2; PGH2-prostaglandin H2; PGG2-prostaglandin G2; PKA-protein kinase A; PKC—protein kinase C; PI3K-phosphoinositide-3 kinase; HIF-1 $\alpha$-hypoxia-inducible factor- $1 \alpha$.

PGE2 exerts its biological actions via binding to its seven-transmembrane, G-protein coupled receptors (GPCRs), termed EP1, EP2, EP3 and EP4 [9]. PGE2 can also function as ligands for the nuclear receptor, and peroxisome proliferator activated receptors (PPAR $\alpha, \operatorname{PPAR} \beta / \delta$ and PPAR $\gamma)$. 
EP receptors and PPARs can be expressed in the endometrium, the ovary, and placenta $[13,14]$. $\mathrm{COX}-2^{-/-}$female mice showed a reduction in ovulation and severe failure in fertilization, implantation and decidualization [15], implying that COX-2-generated prostaglandins and their receptors play an important role in female reproduction. EP2 (-/-) female mice showed the failure of oocyte maturation or cumulus-expansion [16]. EP4-deficient mice die within a few days after birth, because of an impaired cardiovascular remodeling system during birth [17]. Female mice lacking EP1 and EP3 remain elusive in reproduction, therefore most studies focus on the function of EP2 and EP4. PPARs-knockout rodents showed serious abnormalities in reproduction $[18,19]$. In this review, we attempt to summarize present knowledge of prostaglandin E2 receptors in the regulating of various physiological and pathological states of female reproduction.

\section{EP and PPAR $\gamma$ Receptors Signaling}

Although recognizing PGE2 as a ligand, the homology among these receptors is limited. Both EP1 and EP2 share more identities with other prostanoid receptors than with other EPs [20]. Among several conserved regions of EPs, the most highly conserved regions are located in the second extracellular loop (ECL2) and the seventh transmembrane domain (TMVII) [21]. All the EPs had been cloned by 1994 . Since then, the amino acid sequences have been compared, to elucidate the prostaglandin receptor-specific events and understand the structure-function relationships of GPCRs. The aromatic amino acids in the second intercellular loop (ICL2) of EP2 are identified to mediate the Gs protein coupling, which offers an insight into the role of ICL2 in other GPCRs in coupling with G protein [22]. Other studies, focusing on highly conserved residues among EPs of many species, have identified that arginine residue in TMVII is essential to selective G protein coupling [23], while serine residue in TMVI and threonine residue in ECL2 are essential to ligand binding [24].

EP1 is mainly coupled to $\mathrm{Gq} / \mathrm{G} 11$, and induces the $\mathrm{Ca}(2+)$ mobilization and activates protein kinase C (PKC) via the phospholipase C (PLC)-dependent pathway (Figure 1) [25]. Its downstream effectors include tyrosine-protein kinase Src (c-Src), focal adhesion kinase (FAK), and nuclear factor 'kappa-light-chain-enhancer' of activated B-cells (NF- $\mathrm{kB}$ ) [26]. Recent studies show the EP1-mediated PKC is also responsible for cyclic adenosine monophosphate (cAMP) formation, and the following CAMP/PKA/cAMP-response element binding protein (CREB) pathway, which might reveal the interaction among EPs in this pathway [27]. Additionally, EP1 is able to upregulate the expression of hypoxia-inducible factor- $1 \alpha$ (HIF- $1 \alpha$ ), via activation of the phosphoinositide-3 kinase (PI3K)/AKT/ mammalian target of rapamycin (mTOR) signaling by coupling to Gi/Go [28].

EP2 and EP4 have long been known to activate the cAMP/PKA/CREB signaling pathway via Gs (Figure 1). Besides, both receptors are able to induce the translocation of $\beta$-catenin, which is involved in promoting gene transcription [29]. Following activation of cAMP, either of them can also induce a PKA-independent exchange protein activated via the cAMP (EPAC) pathway [30]. However, consistent with different molecular structures, ligand infinities, and distributions, there are several fundamental differences in signaling transduction between EP2 and EP4. The most important one is that EP4, rather than EP2, couples to Gi/Go and is responsible for the subsequent PI3K pathway, including phosphorylation of the extracellular signal-regulated kinase (ERK)1/2, and induction of early growth response protein 1 (EGR-1) [31]. Furthermore, the translocation of $\beta$-catenin and the activation of CREB, achieved by EP2 and EP4, occur through distinct upstream pathways. EP4-mediated activation is PI3K-dependent to a large extent, while EP2-mediated activation is PKA-dependent [32]. In addition, the finding that PI3K inhibits the activity of PKA underlies the connection between these two major pathways [32]. These similarities and differences in signaling, and the close interaction among them, indicate a fine and complex regulation of EP2 and EP4 signaling transduction.

EP3 stimulation mainly induces inhibition of adenylyl cyclase (AC) activity, and enhances $\mathrm{Ca}(2+)$ entry and mobilization via Gi-coupling (Figure 1) [33]. However, among four EPs, EP3 is the most unique, due to its diverse C-terminal tails by alternative splicing. For example, the human EP3 gene, containing 10 exons and 9 introns, generates 9 distinct mRNAs and encodes at least 8 isoforms [34]. 
Consistent with its multiple splicing variants, EP3 has been reported to activate AC and Rho protein via Gs and G12/G13 [35]. Therefore, its downstream targets include the majority of pathways of the other EPs, such as PKA/ $\beta$-catenin [36] and PI3K/AKT signaling [37]. In addition, one bovine isoform of EP3 is indicated to induce phosphatidylinositol turnover and intercellular $\mathrm{Ca}(2+)$ increase by coupling to Gq/G11 [38].

PPARs combine with the 9-cis retinoic acid receptor (RXR), another nuclear receptor, to form a heterodimer. This heterodimer binds to a specific DNA sequence-peroxisome proliferator response element (PPPE) and activates transcription of various target genes [39].

\section{EP Receptors in the Endometrium}

PGE2 is the predominant prostaglandin in endometrium [2], and is indispensable to inducing the vascular permeability, angiogenesis and decidualization during implantation [40]. Decidualization is a process of endometrial stromal cells differentiation into decidual cells, and is a prerequisite for blastocyst implantation. This process is known to be induced by the cyclic adenosine monophosphate (cAMP) and progesterone signaling pathways, which are associated with the gene expression of prolactin (PRL) and the insulin-like growth factor-binding protein 1 (IGFBP-1) as decidual markers [41]. PGE2 was found to be involved in an increase in intracellular cAMP level, and in stimulating the activity of the cAMP dependent protein kinase A (PKA) pathway [42]. PGE2 and progesterone synergize to regulate interleukin-11 (IL-11) expression and secretion via the cAMP/PKA pathway in human endometrial stromal cells, which is critical in initiating decidualization [43]. The concentration of PGE2 in endometrial fluid is considered as a biomarker of endometrial receptivity [44]. In addition, PGE2 is proposed to participate in the endometrial repair process in menstruation, by upregulating the angiogenic factor interleukin-8 (IL-8) [45].

Expressions of EP receptors vary during different phases of human normal endometrium, with inconsistent results. Carson et al. (2002) observed that EP1 is higher in the mid-secretory phase than in the early secretory phase of human endometrium, by high density microarray screening [46]. Catalano et al. (2011) detected that EP1 peaks during the early secretory phase, while EP2, 3 and 4 peak during the mid-secretory phase across the regular human menstrual cycle, via reverse transcription polymerase chain reaction (RT-PCR) [47]. Besides, EP1 is located in different regions of glands depending on different phases [47]. However, Zhu et al. (2018) found that EP1 is expressed highly during the proliferative phase, and decreases sharply during the early secretory phase in both epithelium and stroma cells of the normal endometrium, with the method of immunohistochemistry [48]. All studies indicate that EP1 may be regulated by sex hormones and may also play a role in mediating implantation. Another study showed that EP2 has no change throughout the menstrual cycle, while EP4 is maximum in the late proliferative phase in human nonpregnant endometrium across the menstrual cycle [49].

In mice, EP2 immunostaining was strongly observed at $24 \mathrm{~h}$ and $48 \mathrm{~h}$ after hormone primed, oil-induced decidualization [50]. Hoxa 10 is a highly expressed homeobox transcription factor in decidualizing stromal cells, and deletion of Hoxa-10 in mice showed severe decidualization defects [51]. On day 4 of pregnant Hoxa-10 (-/-) mice, down-regulation of EP3 and EP4 in the uterine stroma suggested that Hoxa-10 might regulate these genes during implantation and decidualization [52]. However, the mechanism of how EP receptors modulate decidualization is still unknown.

\section{Endometriosis}

PGE2, secreted predominantly by endometrial stromal cells (ESCs) and macrophages $(\mathrm{M} \varphi)$, also result in an increase in peritoneal fluid and menstrual fluid of women with endometriosis $[53,54]$. Peritoneal fluid concentrations of PGE2 are higher in women with endometriosis, which is related to the survival and growth of endometriosis lesions [55]. The over-expression of COX-2 and the resulting high production of PGE2 are closely linked to pain, infertility, and a high risk of recurrence [56-58]. A selective COX-2 inhibitor is effective to prevent the ectopic implants in rats [59]. Experiments in vitro, with immune cells derived from women with endometriosis, showed that PGE2's effect on immune 
suppression is achieved by inhibiting the growth of peripheral blood lymphocytes, the phagocytic ability of $\mathrm{M} \varphi$, the chemotaxis of peripheral blood polymorphonuclear leukocytes, and natural killer (NK) cell activity [54,60]. Treatment with PGE2 ultimately leads to increased Escherichia coli colonies in vitro, and endometriotic lesions in vivo [54,60].

EP4 gene expresses the highest in ESCs among four Eps, and, together with EP3 mRNA, is reported to be significantly up-regulated in endometriotic tissue [61]. Inhibition of EP2/EP4 decreases the growth, survival, angiogenesis and innervation of endometriosis lesions, and suppresses the proinflammatory state of dorsal root ganglia neurons to decrease pelvic pain [55].

\section{EP Receptors in Ovarian Development}

Ovulation and fertilization are key processes in female reproduction, which is highly regulated by the follicle-stimulating hormone (FSH) and luteinizing hormone (LH). PGE2 is one of the major mediators in response to the gonadotropins, and is expressed in the ovary. LH regulates PGE2 synthesis and the expression of EP1-4 [3]. The role of EP receptors has been studied most extensively in mice and primates, compared with human.

EP2-/- mice exhibit impaired ovulation and fertilization due to defects in cumulus cell functions [16]. Tamba et al. (2010) suggested the reason might be that EP2 deficiency affected the expression of cAMP-related and epidermal growth factor genes, and ECM-related and chemokine genes in the mice cumulus cells [62]. Human fetal ovarian germ cells express COX-2, EP2 and EP4 receptors, and PGE2 regulates growth and survival factors, such as the neurotrophins brain-derived neurotrophic factor (BDNF), activin A, and Myeloid cell leukemia 1 (MCL1) between 8 and 20 weeks' gestation during ovarian development [63].

Successful ovulation requires elevated follicular PGE2 levels. PGE2 and EP receptors in granulosa cells are essential for successful ovulation, and PGE2 acts directly at mammalian oocytes to delay nuclear maturation [64]. EP2, EP3 and EP4 are expressed in germinal vesicle intact (GV) oocytes from both monkeys and mice [64]. Kim et al. (2016) summarized the expression of EP1-4 within distinct cell types of the monkey ovulatory follicle [3]: EP2 and EP4 in the oocyte couple to G $\alpha$ s to delay nuclear maturation and fertilization, while EP2, EP4 and EP3 isoform 9 in cumulus cells can promote cumulus expansion, oocyte maturation and fertilization. EP2 and EP4 in mural granulosa cells are responsible for the multiple rupture sites in ovulatory follicles, via increasing cAMP, while EP1 and EP3 isoform 5 limit proteolysis in the follicle by decreasing cAMP and increasing intracellular Ca2+. EP3 and EP4 in vascular endothelial cells of stromal vessels participate in maintenance of stable vessels [3].

PGE2 is an important modulator of follicular angiogenesis in non-human primates, while PGE2 and all EP receptor agonists induce migration of human ovarian follicular endothelial cells (hOMECs). EP3 and EP4 were proved to be the primary EP receptors in the endothelial cells of established vessels in the monkey ovarian stroma [65]. By contrast, EP1 and EP2 were identified as main mediators of PGE2-stimulated vascular sprouting in the human ovulatory follicle [66]. Trau et al. (2016) further observed that agonists selective for each EP receptor increased migration of hOMECs, and only EP1 affected sprout length [66].

PGE2 is required for follicle rupture. Markosyan et al. (2009) found that PGE2 increased the Tissue plasminogen activator (tPA) protein via EP2 and EP3, while enhancing the PAI-1 protein via EP1 and EP3 in monkey granulosa cells, suggesting that elevated PGE2 late in the periovulatory interval acts to stimulate proteolysis and follicle rupture [67]. PPAR gamma mRNA was localized primarily to granulosa cells, and its level was decreased $64 \%$ at $24 \mathrm{~h}$ post-hCG (Human chorionic gonadotropin) in rats [68].

EP receptors play different roles in luteal function in ewes: EP1/3 decreases luteal mRNA for LH receptors for luteolysis, while EP2 mediates prevention of luteolysis, via regulation of luteal mRNA for LH receptors to sustain luteal function [69].

Polycystic ovary syndrome (PCOS) is one of the most common endocrine disorders in females, and is characterized by ovulatory dysfunction, hyperandrogenism, and polycystic ovarian morphology, 
based on ultrasound. PGE2 concentrations are increased in the follicular fluid of women with PCOS, and have an inhibitory effect on the expression of the human zince fingere gene (ZNF) 217, a candidate gene for PCOS, in a dose-dependent manner in KGN cells (a human granulosa-like tumor cell line) [70]. Higher amounts of PGE2 were found in polycystic ovary granulosa cells, compared with granulosa cells from normal ovulating women [71].

\section{EP Receptors in the Trophoblast/Embryo}

PGE2 plays an essential role in implantation, consistent with the fact that its secretion increases during the window of implantation [44]. Confined to ethical standards, researchers are limited to animal embryos and trophoblast cells. Embryo implantation is the most unique and key step in mammalian reproduction, and differs with various species. Both a receptive endometrium and well-developed embryos are indispensable to successful implantation. The process of implantation in mouse and human is classified into three stages: apposition, adhesion and penetration. PGE2 plays a role in embryo apposition, and adhesion to the decidua for implantation, mainly through inducing chemokine expression.

Inhibition of COX and EP2 in trophectoderm and inner cell mass greatly decreases the mouse embryo adhesion to the human endometrial epithelial cell (EEC), which can be completely reversed by adding PGE2 or EP2 agonist [44]. Butaprost (an EP2 agonist) increases the mouse embryo adhesion by $20 \%$ compared with control [44], indicating that EP2 functions in embryo adhesion. A similar result is also observed in the adhesion of porcine and the HTR-8/SVneo human trophoblast cell line to fibronectin, one component of ECM [72]. The HTR-8/SVneo human trophoblast cell line expresses all other Eps, such as EP1, EP3 and EP4 [73]. Leukemia inflammatory inhibitor (LIF), a marker of endometrial receptivity, can also increase the synthesis of prostaglandins, and the expression of EP1, EP2, EP4 and COX-2 in the HTR-8/SVneo trophoblast cell line [74]. Expression of COX-2 is absent in the stroma around the embryo during the attachment stage in LIF (-/-) mice, suggesting that the PGs mediate the effect on implantation of LIF via the PG receptors [75].

Over expression of COX-2 and PGE2 are implicated in the down-regulation of Mucin-1 (MUC1), a main glycoprotein mediating trophoblast adhesion, to disturb the embryo adhesion to the right place. Elevated COX-2 and PGE2 are consistent with depressed $\alpha \mathrm{V} \beta 3$ integrin in unreceptive endometrium [76]. This might be due to the fact that PGE2 binds to EP1 and activates the diacylglycerol-mediated PKC pathway, which is a requisite for the tumor necrosis factor-alpha converting enzyme (TACE)/dependent MUC1 proteolytic [77]. In human endometriotic epithelial cells, selective inhibition of EP2 and EP4 decreases membrane-type 1 matrix metalloproteases (MT1-MMP) via the Src/ $\beta$-arrestin 1 protein complex [78]. Both TACE and MT1-MMP are demonstrated to have MUC1 ectodomain proteolysis activity, which might be another mechanism to decrease MUC1 at the implantation site [79,80].

\subsection{ECM Remodeling}

ECM has been reported to play an important role in decidualization, trophoblast invasion, and placentation in early pregnancy [81]. PGE2 has been reported to affect the remodeling and degradation of endometrial ECM via sex steroids, cytokines, and growth factors in early pregnancy [82]. PGE2 binds to EP2 and EP4, and has been reported to stimulate hyaluronan synthesis in the remodeling of sheep cervical ECM [83].

PGE2-induced activation of the cAMP pathway decomposes ECM via decreasing the secretion of chemokine ligand (CCL)7 and CCL2 [62]. Meanwhile, PGE2 via EP2 and EP4 has been reported to mediate IL-1 $\beta$, by inhibiting the secretion of the chemokines CCL7 and CCL2, to enhance ECM disassembly for fertilization [84]. 


\subsection{Trophoblast Invasion}

Invasion of trophoblast cells into the endometrial stroma, and complete remodeling of the maternal spiral arteries by the invading extravillous trophoblasts, are essential processes for the development of the definitive maternal-fetal circulation, and for pregnancy success. PGE2 play an indispensable role in trophoblast migration, proliferation and invasion. EP1, EP2 and EP4 agonists promote the migration of HTR-8/SVneo cells, and LIF stimulates the expression of EP1, EP2 and EP4 to benefit extravillous trophoblast (EVT) invasion in the first trimester of pregnancy [74]. PGE2 binds to EP1 and EP4 to promote HTR-8/ SVneo cell migration, which is mediated by activation of the ERK pathway [73]. However, Biondi et al. demonstrated that PGE2 suppresses HTR-8/SVneo cell proliferation and migration through EP2 and EP4 receptors, by increasing intracellular cAMP [85]. These contradictory results are due to different experimental conditions, such as the different concentrations of PGE2 and the stimulation period. Additionally, human umbilical vein endothelial cells (HUVECs) can express all four EP receptors, but cannot migrate or form sprouts in vitro in response to PGE2 [66].

\subsection{Pregnancy Related Diseases}

PGE2 is found to be increased in the cervical ovulatory mucus [86] and the endometrium [76,87] of Recurrent Miscarriage (RM) women, compared to healthy controls during implantation. Until now, reports on the EP receptor's expression in the pathological mechanism of RM have been rare. Our research group has recently found that PGE2, in combination with the EP3 receptor in extravillous trophoblasts, contributes to a decreased production of $\beta-\mathrm{hCG}$ and progesterone via Gi1 and AC, thus causing reduced levels of cAMP and deactivated activity of PKA [88]. An EP3 antagonist (L-798,106) down-regulates EP3 expression without influencing the $\beta$-hCG expression in JEG-3 cells, indicating that L-798,106 might be a 'potential therapeutic candidate' for the treatment of unexplained $\mathrm{RM}$ [88]. In addition, our research group observed that PPAR $\gamma$ is diminished in macrophages of RM placentas compared to those of healthy controls in the first trimester, which is related to a specific inflammatary reaction against the fetus [89].

The expression of COX-2 and EP3 receptors were significantly elevated at $24 \mathrm{~h}$ after ischemia-reperfusion injury, with a rat model of intrauterine growth restriction [90]. Lower expression of COX-2 and PGE2 in the embryos of streptozotocin-induced diabetic rats and their yolk sacs is associated with a malformed embryo and unhealthy placenta in gestational diabetes mellitus (GDM) [91].

\section{Conclusions}

Numerous studies have revealed the presence and significance of PGE2 in the reproductive system. PGE2 and EP receptors are present in the endometrium, ovary and trophoblast of various species in pathological conditions. Although PGE2 is related to endometriosis, PCOS, RM, FGR and GDM, the mechanism of EP receptors is still limited. Further research is required to investigate whether prostaglandin E2 receptors are involved in the course of the pathological state of the female reproductive system. In addition, more investigations should be performed so that EP receptor agonists or antagonists can be applied clinically to improve reproductive disorders.

Author Contributions: Y.Y., P.L. and J.Z. performed the literature searching and wrote the manuscript. U.J. and V.v.S. revised the manuscript. All authors have read and agreed to the published version of the manuscript.

Funding: The study was founded by the China Scholarship Council (CSC).

Acknowledgments: We would like to thank Christina Kuhn, Martina Rahmeh, Simone Hofmann and Marianne Vogel for technical support.

Conflicts of Interest: All authors declare no conflict of interest. 


\section{Abbreviations}

\begin{tabular}{|c|c|}
\hline PG & Prostaglandin \\
\hline AA & arachidonic acid \\
\hline PLA2 & phospholipase A2 \\
\hline PGG2 & prostaglandin G2 \\
\hline PGH2 & prostaglandin $\mathrm{H} 2$ \\
\hline COX & cyclooxygenase \\
\hline TXA2 & hromboxane A2 \\
\hline PGES & PGE synthase \\
\hline MRP4 & multidrug resistance protein 4 \\
\hline PGT & prostaglandin transporter \\
\hline GPCRs & G-protein coupled receptors \\
\hline $\mathrm{EP}$ & prostaglandin E receptor \\
\hline PPARs & Peroxisome proliferator activated receptors \\
\hline ECL2 & second extracellular loop \\
\hline TMVII & seventh transmembrane domain \\
\hline ICL2 & cond intercellular loop \\
\hline PKC & protein kinase $\mathrm{C}$ \\
\hline PLC & phospholipase C \\
\hline FAK & focal adhesion kinase \\
\hline cAMP & cyclic adenosine monophosphate \\
\hline CREB & response element binding protein \\
\hline HIF-1 $\alpha$ & hypoxia-inducible factor- $1 \alpha$ \\
\hline PI3K & phosphoinositide-3 kinase \\
\hline mTOR & mammalian target of rapamycin \\
\hline ERK & extracellular signal-regulated kinase \\
\hline EGR-1 & early growth response protein 1 \\
\hline $\mathrm{AC}$ & adenylyl cyclase \\
\hline RXR & retinoic acid receptor \\
\hline PPPE & peroxisome proliferator response element \\
\hline IL-8 & interleukin-8 \\
\hline RT-PCR & reverse transcription polymerase chain reaction \\
\hline ESCs & endometrial stromal cells \\
\hline $\mathrm{M} \varphi$ & macrophages \\
\hline NK & natural killer \\
\hline FSH & follicle-stimulating hormone \\
\hline $\mathrm{LH}$ & luteinizing hormone \\
\hline BDNF & brain-derived neurotrophic factor \\
\hline GV & germinal vesicle \\
\hline hOMECs & human ovarian follicular endothelial cells \\
\hline EEC & endometrial epithelial cell \\
\hline TACE & tumor necrosis factor-alpha converting enzyme \\
\hline MT1-MMP & membrane-type 1 matrix metalloproteases \\
\hline HUVECs & Human umbilical vein endothelial cells \\
\hline ECM & extracellular matrix \\
\hline
\end{tabular}

\section{References}

1. Sugimoto, Y.; Inazumi, T.; Tsuchiya, S. Roles of prostaglandin receptors in female reproduction. J. Biochem. 2015, 157, 73-80. [CrossRef] [PubMed]

2. Demers, L.M.; Rees, M.C.; Turnbull, A.C. Arachidonic acid metabolism by the non-pregnant human uterus. Prostaglandins Leukot. Med. 1984, 14, 175-180. [CrossRef]

3. Kim, S.O.; Duffy, D.M. Mapping PTGERs to the Ovulatory Follicle: Regional Responses to the Ovulatory PGE2 Signal. Biol. Reprod. 2016, 95, 33. [CrossRef] [PubMed] 
4. Duchesne, M.J.; Thaler-Dao, H.; de Paulet, A.C. Prostaglandin synthesis in human placenta and fetal membranes. Prostaglandins 1978, 15, 19-42. [CrossRef]

5. Kalinski, P. Regulation of immune responses by prostaglandin E2. J. Immunol. 2012, 188, 21-28. [CrossRef]

6. Lala, P.K.; Kennedy, T.G.; Parhar, R.S. Suppression of lymphocyte alloreactivity by early gestational human decidua. II. Characterization of the suppressor mechanisms. Cell. Immunol. 1988, 116, 411-422. [CrossRef]

7. Clark, J.D.; Lin, L.L.; Kriz, R.W.; Ramesha, C.S.; Sultzman, L.A.; Lin, A.Y.; Milona, N.; Knopf, J.L. A novel arachidonic acid-selective cytosolic PLA2 contains a $\mathrm{Ca}(2+)$-dependent translocation domain with homology to PKC and GAP. Cell 1991, 65, 1043-1051. [CrossRef]

8. Smith, W.L. Prostaglandin biosynthesis and its compartmentation in vascular smooth muscle and endothelial cells. Ann. Rev. Physiol. 1986, 48, 251-262. [CrossRef]

9. Narumiya, S.; Sugimoto, Y.; Ushikubi, F. Prostanoid receptors: Structures, properties, and functions. Physiol. Rev. 1999, 79, 1193-1226. [CrossRef]

10. Reid, G.; Wielinga, P.; Zelcer, N.; van der Heijden, I.; Kuil, A.; de Haas, M.; Wijnholds, J.; Borst, P. The human multidrug resistance protein MRP4 functions as a prostaglandin efflux transporter and is inhibited by nonsteroidal antiinflammatory drugs. Proc. Natl. Acad. Sci. USA 2003, 100, 9244-9249. [CrossRef]

11. Holla, V.R.; Backlund, M.G.; Yang, P.; Newman, R.A.; DuBois, R.N. Regulation of prostaglandin transporters in colorectal neoplasia. Cancer Prev. Res. 2008, 1, 93-99. [CrossRef] [PubMed]

12. Subbaramaiah, K.; Hudis, C.A.; Dannenberg, A.J. The prostaglandin transporter regulates adipogenesis and aromatase transcription. Cancer Prev. Res. 2011, 4, 194-206. [CrossRef] [PubMed]

13. Bogacka, I.; Bogacki, M.; Gaglewska, M.; Kurzynska, A.; Wasielak, M. In vitro effect of peroxisome proliferator activated receptor (PPAR) ligands on prostaglandin E2 synthesis and secretion by porcine endometrium during the estrous cycle and early pregnancy. J. Physiol. Pharmacol. 2013, 64, 47-54.

14. Niringiyumukiza, J.D.; Cai, H.; Xiang, W. Prostaglandin E2 involvement in mammalian female fertility: Ovulation, fertilization, embryo development and early implantation. Reprod. Biol. Endocrinol. 2018, 16, 43. [CrossRef]

15. Lim, H.; Paria, B.C.; Das, S.K.; Dinchuk, J.E.; Langenbach, R.; Trzaskos, J.M.; Dey, S.K. Multiple female reproductive failures in cyclooxygenase 2-deficient mice. Cell 1997, 91, 197-208. [CrossRef]

16. Hizaki, H.; Segi, E.; Sugimoto, Y.; Hirose, M.; Saji, T.; Ushikubi, F.; Matsuoka, T.; Noda, Y.; Tanaka, T.; Yoshida, N.; et al. Abortive expansion of the cumulus and impaired fertility in mice lacking the prostaglandin E receptor subtype EP(2). Proc. Natl. Acad. Sci. USA 1999, 96, 10501-10506. [CrossRef]

17. Sugimoto, Y. Physiological functions of prostanoid receptors and their subtypes. Nihon Yakurigaku Zasshi 2000, 115, 131-141. [CrossRef]

18. Barak, Y.; Nelson, M.C.; Ong, E.S.; Jones, Y.Z.; Ruiz-Lozano, P.; Chien, K.R.; Koder, A.; Evans, R.M. PPAR gamma is required for placental, cardiac, and adipose tissue development. Mol. Cell 1999, 4, 585-595. [CrossRef]

19. Barak, Y.; Liao, D.; He, W.; Ong, E.S.; Nelson, M.C.; Olefsky, J.M.; Boland, R.; Evans, R.M. Effects of peroxisome proliferator-activated receptor delta on placentation, adiposity, and colorectal cancer. Proc. Natl. Acad. Sci. USA 2002, 99, 303-308. [CrossRef]

20. Toh, H.; Ichikawa, A.; Narumiya, S. Molecular evolution of receptors for eicosanoids. FEBS Lett. 1995, 361, 17-21. [CrossRef]

21. Sugimoto, Y.; Narumiya, S. Prostaglandin E receptors. J. Biol. Chem. 2007, 282, 11613-11617. [CrossRef] [PubMed]

22. Zheng, C.; Chen, L.; Chen, X.; He, X.; Yang, J.; Shi, Y.; Zhou, N. The second intracellular loop of the human cannabinoid CB2 receptor governs $\mathrm{G}$ protein coupling in coordination with the carboxyl terminal domain. PLOS ONE 2013, 8, e63262.

23. Negishi, M.; Irie, A.; Sugimoto, Y.; Namba, T.; Ichikawa, A. Selective coupling of prostaglandin E receptor EP3D to Gi and Gs through interaction of alpha-carboxylic acid of agonist and arginine residue of seventh transmembrane domain. J. Biol. Chem. 1995, 270, 16122-16127. [CrossRef] [PubMed]

24. Stillman, B.A.; Audoly, L.; Breyer, R.M. A conserved threonine in the second extracellular loop of the human EP2 and EP4 receptors is required for ligand binding. Eur. J. Pharmacol. 1998, 357, 73-82. [CrossRef]

25. Ni, W.J.; Tang, L.Q.; Zhou, H.; Ding, H.H.; Qiu, Y.Y. Renoprotective effect of berberine via regulating the PGE2 -EP1-Galphaq-Ca(2+) signalling pathway in glomerular mesangial cells of diabetic rats. J. Cell. Mol. Med. 2016, 20, 1491-1502. [CrossRef] 
26. Bai, X.; Wang, J.; Guo, Y.; Pan, J.; Yang, Q.; Zhang, M.; Li, H.; Zhang, L.; Ma, J.; Shi, F.; et al. Prostaglandin E2 stimulates beta1-integrin expression in hepatocellular carcinoma through the EP1 receptor/PKC/NF-kappaB pathway. Sci. Rep. 2014, 4, 6538. [CrossRef]

27. Gonzalez, A.A.; Salinas-Parra, N.; Leach, D.; Navar, L.G.; Prieto, M.C. PGE2 upregulates renin through E-prostanoid receptor 1 via PKC/CAMP/CREB pathway in M-1 cells. Am. J. Physiol. Renal Physiol. 2017, 313, F1038-F1049. [CrossRef]

28. Ji, R.; Chou, C.L.; Xu, W.; Chen, X.B.; Woodward, D.F.; Regan, J.W. EP1 prostanoid receptor coupling to G i/o up-regulates the expression of hypoxia-inducible factor- 1 alpha through activation of a phosphoinositide-3 kinase signaling pathway. Mol. Pharmacol. 2010, 77, 1025-1036. [CrossRef]

29. Fujino, H.; West, K.A.; Regan, J.W. Phosphorylation of glycogen synthase kinase-3 and stimulation of T-cell factor signaling following activation of EP2 and EP4 prostanoid receptors by prostaglandin E2. J. Biol. Chem. 2002, 277, 2614-2619. [CrossRef]

30. Samuchiwal, S.K.; Balestrieri, B.; Raff, H.; Boyce, J.A. Endogenous prostaglandin E2 amplifies IL-33 production by macrophages through an E prostanoid (EP)2/EP4-cAMP-EPAC-dependent pathway. J. Biol. Chem. 2017, 292, 8195-8206. [CrossRef]

31. Fujino, H.; Regan, J.W. EP(4) prostanoid receptor coupling to a pertussis toxin-sensitive inhibitory G protein. Mol. Pharmacol. 2006, 69, 5-10. [CrossRef] [PubMed]

32. Fujino, H.; Salvi, S.; Regan, J.W. Differential regulation of phosphorylation of the cAMP response element-binding protein after activation of EP2 and EP4 prostanoid receptors by prostaglandin E2. Mol. Pharmacol. 2005, 68, 251-259. [CrossRef] [PubMed]

33. Irie, A.; Segi, E.; Sugimoto, Y.; Ichikawa, A.; Negishi, M. Mouse prostaglandin E receptor EP3 subtype mediates calcium signals via $\mathrm{Gi}$ in cDNA-transfected Chinese hamster ovary cells. Biochem. Biophys. Res. Commun. 1994, 204, 303-309. [CrossRef]

34. Kotani, M.; Tanaka, I.; Ogawa, Y.; Usui, T.; Tamura, N.; Mori, K.; Narumiya, S.; Yoshimi, T.; Nakao, K. Structural organization of the human prostaglandin EP3 receptor subtype gene (PTGER3). Genomics 1997, 40, 425-434. [CrossRef]

35. Hatae, N.; Sugimoto, Y.; Ichikawa, A. Prostaglandin receptors: Advances in the study of EP3 receptor signaling. J. Biochem. 2002, 131, 781-784. [CrossRef]

36. Chen, D.; Tang, J.; Wan, Q.; Zhang, J.; Wang, K.; Shen, Y.; Yu, Y. E-Prostanoid 3 Receptor Mediates Sprouting Angiogenesis Through Suppression of the Protein Kinase A/beta-Catenin/Notch Pathway. Arterioscler. Thromb. Vasc. Biol. 2017, 37, 856-866. [CrossRef]

37. Fujino, H.; Toyomura, K.; Chen, X.B.; Regan, J.W.; Murayama, T. Prostaglandin E(2) regulates cellular migration via induction of vascular endothelial growth factor receptor-1 in HCA-7 human colon cancer cells. Biochem. Pharmacol. 2011, 81, 379-387. [CrossRef]

38. Namba, T.; Sugimoto, Y.; Negishi, M.; Irie, A.; Ushikubi, F.; Kakizuka, A.; Ito, S.; Ichikawa, A.; Narumiya, S. Alternative splicing of C-terminal tail of prostaglandin E receptor subtype EP3 determines G-protein specificity. Nature 1993, 365, 166-170. [CrossRef]

39. Lalloyer, F.; Staels, B. Fibrates, glitazones, and peroxisome proliferator-activated receptors. Arterioscler. Thromb. Vasc. Biol. 2010, 30, 894-899. [CrossRef]

40. Salleh, N. Diverse roles of prostaglandins in blastocyst implantation. Sci. World J. 2014, $2014,968141$. [CrossRef]

41. Logan, P.C.; Ponnampalam, A.P.; Steiner, M.; Mitchell, M.D. Effect of cyclic AMP and estrogen/progesterone on the transcription of DNA methyltransferases during the decidualization of human endometrial stromal cells. Mol. Hum. Reprod. 2013, 19, 302-312. [CrossRef]

42. Yee, G.M.; Kennedy, T.G. Prostaglandin E2, cAMP and cAMP-dependent protein kinase isozymes during decidualization of rat endometrial stromal cells in vitro. Prostaglandins 1993, 46, 117-138. [CrossRef]

43. Dimitriadis, E.; Stoikos, C.; Baca, M.; Fairlie, W.D.; McCoubrie, J.E.; Salamonsen, L.A. Relaxin and prostaglandin $\mathrm{E}(2)$ regulate interleukin 11 during human endometrial stromal cell decidualization. J. Clin. Endocrinol. Metab. 2005, 90, 3458-3465. [CrossRef]

44. Vilella, F.; Ramirez, L.; Berlanga, O.; Martinez, S.; Alama, P.; Meseguer, M.; Pellicer, A.; Simon, C. PGE2 and PGF2alpha concentrations in human endometrial fluid as biomarkers for embryonic implantation. J. Clin. Endocrinol. Metab. 2013, 98, 4123-4132. [CrossRef] 
45. Maybin, J.A.; Hirani, N.; Jabbour, H.N.; Critchley, H.O. Novel roles for hypoxia and prostaglandin E2 in the regulation of IL-8 during endometrial repair. Am. J. Pathol. 2011, 178, 1245-1256. [CrossRef]

46. Carson, D.D.; Lagow, E.; Thathiah, A.; Al-Shami, R.; Farach-Carson, M.C.; Vernon, M.; Yuan, L.; Fritz, M.A.; Lessey, B. Changes in gene expression during the early to mid-luteal (receptive phase) transition in human endometrium detected by high-density microarray screening. Mol. Hum. Reprod. 2002, 8, 871-879. [CrossRef]

47. Catalano, R.D.; Wilson, M.R.; Boddy, S.C.; Jabbour, H.N. Comprehensive expression analysis of prostanoid enzymes and receptors in the human endometrium across the menstrual cycle. Mol. Hum. Reprod. 2011, 17, 182-192. [CrossRef]

48. Zhu, J.; Mayr, D.; Kuhn, C.; Mahner, S.; Jeschke, U.; von Schonfeldt, V. Prostaglandin E2 receptor EP1 in healthy and diseased human endometrium. Histochem. Cell Biol. 2018, 149, 153-160. [CrossRef]

49. Milne, S.A.; Perchick, G.B.; Boddy, S.C.; Jabbour, H.N. Expression, localization, and signaling of PGE(2) and EP2/EP4 receptors in human nonpregnant endometrium across the menstrual cycle. J. Clin. Endocrinol. Metab. 2001, 86, 4453-4459. [CrossRef]

50. Pakrasi, P.L.; Jain, A.K. Cyclooxygenase-2 derived PGE2 and PGI2 play an important role via EP2 and PPARdelta receptors in early steps of oil induced decidualization in mice. Placenta 2008, 29, 523-530. [CrossRef]

51. Rahman, M.A.; Li, M.; Li, P.; Wang, H.; Dey, S.K.; Das, S.K. Hoxa-10 deficiency alters region-specific gene expression and perturbs differentiation of natural killer cells during decidualization. Dev. Biol. 2006, 290, 105-117. [CrossRef]

52. Lim, H.; Ma, L.; Ma, W.G.; Maas, R.L.; Dey, S.K. Hoxa-10 regulates uterine stromal cell responsiveness to progesterone during implantation and decidualization in the mouse. Mol. Endocrinol. 1999, 13, 1005-1017. [CrossRef]

53. Herath, S.; Fischer, D.P.; Werling, D.; Williams, E.J.; Lilly, S.T.; Dobson, H.; Bryant, C.E.; Sheldon, I.M. Expression and function of Toll-like receptor 4 in the endometrial cells of the uterus. Endocrinology 2006, 147, 562-570. [CrossRef]

54. Khan, K.N.; Kitajima, M.; Yamaguchi, N.; Fujishita, A.; Nakashima, M.; Ishimaru, T.; Masuzaki, H. Role of prostaglandin E2 in bacterial growth in women with endometriosis. Hum. Reprod. 2012, 27, 3417-3424. [CrossRef]

55. Arosh, J.A.; Lee, J.; Balasubbramanian, D.; Stanley, J.A.; Long, C.R.; Meagher, M.W.; Osteen, K.G.; Bruner-Tran, K.L.; Burghardt, R.C.; Starzinski-Powitz, A.; et al. Molecular and preclinical basis to inhibit PGE2 receptors EP2 and EP4 as a novel nonsteroidal therapy for endometriosis. Proc. Natl. Acad. Sci. USA 2015, 112, 9716-9721. [CrossRef]

56. Lee, T.C.; Ho, H.C. Effects of prostaglandin E2 and vascular endothelial growth factor on sperm might lead to endometriosis-associated infertility. Fertil. Steril. 2011, 95, 360-362. [CrossRef]

57. Lane, N.E. Pain management in osteoarthritis: The role of COX-2 inhibitors. J. Rheumatol. Suppl. 1997, 49, 20-24.

58. Gambera, L.; Serafini, F.; Morgante, G.; Focarelli, R.; De Leo, V.; Piomboni, P. Sperm quality and pregnancy rate after COX-2 inhibitor therapy of infertile males with abacterial leukocytospermia. Hum. Reprod. 2007, 22, 1047-1051. [CrossRef]

59. Machado, D.E.; Berardo, P.T.; Landgraf, R.G.; Fernandes, P.D.; Palmero, C.; Alves, L.M.; Abrao, M.S.; Nasciutti, L.E. A selective cyclooxygenase-2 inhibitor suppresses the growth of endometriosis with an antiangiogenic effect in a rat model. Fertil. Steril. 2010, 93, 2674-2679. [CrossRef]

60. Chuang, P.C.; Lin, Y.J.; Wu, M.H.; Wing, L.Y.; Shoji, Y.; Tsai, S.J. Inhibition of CD36-dependent phagocytosis by prostaglandin E2 contributes to the development of endometriosis. Am. J. Pathol. 2010, 176, 850-860. [CrossRef]

61. Takenaka, Y.; Taniguchi, F.; Miyakoda, H.; Takai, E.; Terakawa, N.; Harada, T. Lipopolysaccharide promoted proliferation and invasion of endometriotic stromal cells via induction of cyclooxygenase-2 expression. Fertil. Steril. 2010, 93, 325-327. [CrossRef] [PubMed]

62. Tamba, S.; Yodoi, R.; Morimoto, K.; Inazumi, T.; Sukeno, M.; Segi-Nishida, E.; Okuno, Y.; Tsujimoto, G.; Narumiya, S.; Sugimoto, Y. Expression profiling of cumulus cells reveals functional changes during ovulation and central roles of prostaglandin EP2 receptor in cAMP signaling. Biochimie 2010, 92, 665-675. [CrossRef] 
63. Bayne, R.A.; Eddie, S.L.; Collins, C.S.; Childs, A.J.; Jabbour, H.N.; Anderson, R.A. Prostaglandin E2 as a regulator of germ cells during ovarian development. J. Clin. Endocrinol. Metab. 2009, 94, 4053-4060. [CrossRef] [PubMed]

64. Duffy, D.M.; McGinnis, L.K.; Vandevoort, C.A.; Christenson, L.K. Mammalian oocytes are targets for prostaglandin E2 (PGE2) action. Reprod. Biol. Endocrinol. 2010, 8, 131. [CrossRef] [PubMed]

65. Trau, H.A.; Davis, J.S.; Duffy, D.M. Angiogenesis in the primate ovulatory follicle is stimulated by luteinizing hormone via prostaglandin E2. Biol. Reprod. 2015, 92, 15. [CrossRef] [PubMed]

66. Trau, H.A.; Brannstrom, M.; Curry, T.E., Jr.; Duffy, D.M. Prostaglandin E2 and vascular endothelial growth factor A mediate angiogenesis of human ovarian follicular endothelial cells. Hum. Reprod. 2016, 31, 436-444. [CrossRef]

67. Markosyan, N.; Duffy, D.M. Prostaglandin E2 acts via multiple receptors to regulate plasminogen-dependent proteolysis in the primate periovulatory follicle. Endocrinology 2009, 150, 435-444. [CrossRef]

68. Komar, C.M.; Braissant, O.; Wahli, W.; Curry, T.E., Jr. Expression and localization of PPARs in the rat ovary during follicular development and the periovulatory period. Endocrinology 2001, 142, 4831-4838. [CrossRef]

69. Weems, Y.S.; Nett, T.M.; Rispoli, L.A.; Davis, T.L.; Johnson, D.L.; Uchima, T.; Raney, A.; Lennon, E.; Harbert, T.; Bowers, G.; et al. Effects of prostaglandin $\mathrm{E}$ and $\mathrm{F}$ receptor agonists in vivo on luteal function in ewes. Prostaglandins Other Lipid Mediat. 2010, 92, 67-72. [CrossRef]

70. Zhai, J.; Li, S.; Cheng, X.; Chen, Z.J.; Li, W.; Du, Y. A candidate pathogenic gene, zinc finger gene 217 (ZNF217) may contribute to polycystic ovary syndrome through prostaglandin E2. Acta Obstet. Gynecol. Scand. 2020, 99, 119-126. [CrossRef]

71. Navarra, P.; Andreani, C.L.; Lazzarin, N.; Pierro, E.; Mirtella, A.; Lanzone, A.; Mancuso, S. Increased production and release of prostaglandin-E2 by human granulosa cells from polycystic ovaries. Prostaglandins 1996, 52, 187-197. [CrossRef]

72. Waclawik, A.; Kaczynski, P.; Jabbour, H.N. Autocrine and paracrine mechanisms of prostaglandin E(2) action on trophoblast/conceptus cells through the prostaglandin E(2) receptor (PTGER2) during implantation. Endocrinology 2013, 154, 3864-3876. [CrossRef] [PubMed]

73. Nicola, C.; Timoshenko, A.V.; Dixon, S.J.; Lala, P.K.; Chakraborty, C. EP1 receptor-mediated migration of the first trimester human extravillous trophoblast: The role of intracellular calcium and calpain. J. Clin. Endocrinol. Metab. 2005, 90, 4736-4746. [CrossRef] [PubMed]

74. Horita, H.; Kuroda, E.; Hachisuga, T.; Kashimura, M.; Yamashita, U. Induction of prostaglandin E2 production by leukemia inhibitory factor promotes migration of first trimester extravillous trophoblast cell line, HTR-8/SVneo. Hum. Reprod. 2007, 22, 1801-1809. [CrossRef]

75. Song, H.; Lim, H.; Das, S.K.; Paria, B.C.; Dey, S.K. Dysregulation of EGF family of growth factors and COX-2 in the uterus during the preattachment and attachment reactions of the blastocyst with the luminal epithelium correlates with implantation failure in LIF-deficient mice. Mol. Endocrinol. 2000, 14, 1147-1161. [CrossRef]

76. Banerjee, P.; Jana, S.K.; Pasricha, P.; Ghosh, S.; Chakravarty, B.; Chaudhury, K. Proinflammatory cytokines induced altered expression of cyclooxygenase-2 gene results in unreceptive endometrium in women with idiopathic recurrent spontaneous miscarriage. Fertil. Steril. 2013, 99, 179-187. [CrossRef]

77. Woodward, D.F.; Jones, R.L.; Narumiya, S. International Union of Basic and Clinical Pharmacology. LXXXIII: Classification of prostanoid receptors, updating 15 years of progress. Pharmacol. Rev. 2011, 63, 471-538. [CrossRef]

78. Lee, J.; Banu, S.K.; Subbarao, T.; Starzinski-Powitz, A.; Arosh, J.A. Selective inhibition of prostaglandin E2 receptors EP2 and EP4 inhibits invasion of human immortalized endometriotic epithelial and stromal cells through suppression of metalloproteinases. Mol. Cell. Endocrinol. 2011, 332, 306-313. [CrossRef]

79. Thathiah, A.; Blobel, C.P.; Carson, D.D. Tumor necrosis factor-alpha converting enzyme/ADAM 17 mediates MUC1 shedding. J. Biol. Chem. 2003, 278, 3386-3394. [CrossRef]

80. Thathiah, A.; Carson, D.D. MT1-MMP mediates MUC1 shedding independent of TACE/ADAM17. Biochem. J. 2004, 382, 363-373. [CrossRef]

81. Sharma, S.; Godbole, G.; Modi, D. Decidual Control of Trophoblast Invasion. Am. J. Reprod. Immunol. 2016, 75, 341-350. [CrossRef] 
82. Salgado, R.M.; Covarrubias, A.C.; Favaro, R.R.; Serrano-Nascimento, C.; Nunes, M.T.; Zorn, T.M. Estradiol induces transcriptional and posttranscriptional modifications in versican expression in the mouse uterus. J. Mol. Histol. 2013, 44, 221-229. [CrossRef]

83. Kershaw-Young, C.M.; Khalid, M.; McGowan, M.R.; Pitsillides, A.A.; Scaramuzzi, R.J. The mRNA expression of prostaglandin E receptors EP2 and EP4 and the changes in glycosaminoglycans in the sheep cervix during the estrous cycle. Theriogenology 2009, 72, 251-261. [CrossRef] [PubMed]

84. Mosher, A.A.; Rainey, K.J.; Giembycz, M.A.; Wood, S.; Slater, D.M. Prostaglandin E2 represses interleukin 1 beta-induced inflammatory mediator output from pregnant human myometrial cells through the EP2 and EP4 receptors. Biol. Reprod. 2012, 87, 1-10. [CrossRef] [PubMed]

85. Biondi, C.; Ferretti, M.E.; Pavan, B.; Lunghi, L.; Gravina, B.; Nicoloso, M.S.; Vesce, F.; Baldassarre, G. Prostaglandin E2 inhibits proliferation and migration of HTR-8/SVneo cells, a human trophoblast-derived cell line. Placenta 2006, 27, 592-601. [CrossRef] [PubMed]

86. Ryantova, M.; Ulcova-Gallova, Z.; Micanova, Z.; Bibkova, K.; Sediva, B. Levels of prostaglandin E2 (PGE2) in cervical ovulatory mucus in women with spontaneous miscarriages. Ceska Gynekol. 2008, 73, 98-101. [PubMed]

87. Banerjee, P.; Ghosh, S.; Dutta, M.; Subramani, E.; Khalpada, J.; Roychoudhury, S.; Chakravarty, B.; Chaudhury, K. Identification of key contributory factors responsible for vascular dysfunction in idiopathic recurrent spontaneous miscarriage. PLoS ONE 2013, 8, e80940. [CrossRef]

88. Ye, Y.; Vattai, A.; Ditsch, N.; Kuhn, C.; Rahmeh, M.; Mahner, S.; Ripphahn, M.; Immler, R.; Sperandio, M.; Jeschke, U.; et al. Prostaglandin E2 receptor 3 signaling is induced in placentas with unexplained recurrent pregnancy losses. Endocr. Connect. 2018, 7, 749-761. [CrossRef]

89. Kolben, T.M.; Rogatsch, E.; Vattai, A.; Hester, A.; Kuhn, C.; Schmoeckel, E.; Mahner, S.; Jeschke, U.; Kolben, T. PPARgamma Expression Is Diminished in Macrophages of Recurrent Miscarriage Placentas. Int. J. Mol. Sci. 2018, 19, 1872. [CrossRef]

90. Yamazaki, K.; Endo, T.; Kitajima, Y.; Manase, K.; Nagasawa, K.; Honnma, H.; Hayashi, T.; Kudo, R.; Saito, T. Elevation of both cyclooxygenase-2 and prostaglandin E2 receptor EP3 expressions in rat placenta after uterine artery ischemia-reperfusion. Placenta 2006, 27, 395-401. [CrossRef]

91. El-Bassiouni, E.A.; Helmy, M.H.; Abou Rawash, N.; El-Zoghby, S.M.; Kamel, M.A.; Abou Raya, A.N. Embryopathy in experimental diabetic gestation: Assessment of PGE2 level, gene expression of cyclooxygenases and apoptosis. Br. J. Biomed. Sci. 2005, 62, 161-165. [CrossRef] [PubMed] 